\title{
FROM REVELATION TO COMMODITY: PERFORMING MESSENGERS, LANGUAGE AND NEWS FROM THE YORK CYCLE TO BEN JONSON*
}

$\mathrm{T}$ The despatch and receipt of messengers, the crying of proclamations, the circulation of books, letters and other documents are crucial elements in many of the dramatic texts of the premodern period. Ranging from the Angel who visits the Virgin Mary in the York Annunciation pageant through Rumour in Shakespeare's 2 Henry IV to the envoys who populate the history plays and city comedies of the Stuart stage, messengers provide insights into the wider changes to the material and intellectual contexts of English drama in this period, changes which were themselves driven by developments in the organisation, technology and conceptualisation of communication.

This article offers an analysis of the representation of communication in early English drama, examining the ways in which dramatists stage and interrogate the commissioning, delivering and interpreting of messages. Of central concern are late-medieval and Renaissance conceptions of language and communication. In Timber: or Discoveries; Made Upon Men and Matter, Ben Jonson calls language "the instrument of society". It is a significant phrase, for not only does it emphasise the use of speech in social exchange, it also acknowledges language's instrumental role in affecting personal and institutional relations. We aim to explore this conception of language by analysing the effects of communication on personal, social and political bonds in early English drama.

The period from 1360 to 1630 was crucial in the development of modern understandings of communication. Dramatic depictions of messengers arise from a history of communication and transport, institutions and practices which were starting to undergo marked change. An increasingly centralised system of state government, coupled with the concomitant loosening of aristocratic land ownership, the increasing complexities of international trade and financial exchange, and the marked expansion in the institutions of the law and civil bureaucracy, were matched by an enormous increase in demand for transport and communication services. These developments were reflected in a drama which itself experienced profound material and conceptual changes and was increasingly commo dified in the burgeoning institution of the professional theatre.

Scenes from Elizabethan and Jacobean plays which stage the exchange of information and news are a prime index of these changing circumstances. But they also draw upon a long tradition of dramatic representations of oral and written communication with its roots in the urban religious drama of the fourteenth century. Here, the figure of the messenger (whether human or divine) plays a number of highly significant roles. The first section of this essay will explore the ways in which dramatic texts and performances represented ideas of news, revelation, rumour, gossip and counsel, through the medium of the message and the figure of the messenger, and how ideas of good and bad government, civil order, right and wrong belief were encoded.

Communication, Truth and Treason: The Medieval Cycle Plays

The religious plays of late-medieval England were created before the explosion in information exchange brought about by the introduction of print. It is not, therefore, surprising that their attitude towards the generation and circulation of news is very different from that which increasingly characterised later drama. That is not to say, however, that the cycle plays of York, Wakefield, Chester, Coventry and $\mathrm{N}$-Town have no interest in the generation of news and information. These plays took great interest in such matters, using them, as we shall see, to explore through their performance wider issues of religious faith, morality and the legitimacy or otherwise of worldly rulers.

Messengers are ubiquitous in medieval religious drama: angels and prophets carry God's word to his chosen human agents; heralds and nuncios precede worldly princes into the acting area with boastful, threatening speeches; troops of knights flit between the cities and courts of the earthly powers with requests and instructions. ${ }^{2}$ The fraught political scenes of the Passion are tied together by the delegations of soldiers that thread their way between the palaces of the High Priests Annas and Caiaphas, King Herod and Pontius Pilate. Christ himself, the archetypal bringer of Good News, is dragged from palace to palace and his story is repeatedly retold as the political authorities try to decide what to do with him. Meanwhile, gatekeepers, beadles and janitors take word of each arrival to their masters within, returning with grudging responses from their chambers. 
The cycle plays are thus held together by the activities of messengers and the circulation of "news". But message-bringing has a very particular role here. The messengers of the cycle plays only rarely do what messengers had done in classical drama, that is bring previously unknown information to both the recipient and the audience: real news that will tilt the narrative in a new direction. Given the almost universal familiarity of late medieval folk with the broad outline of the Christian story it was only rarely that these angels, prophets and nuncios said anything that was genuinely "news" to the audience, and the playwrights constructed their plays with this in mind. Consequently it is how characters react to the information imparted that is important, not the information itself.

When Mary responds with humble acceptance to the astonishing news that Gabriel imparts at the Annunciation, she signals her absolute obedience to God and hence her worthiness to bear His Son. When Herod receives news that a king has been born with rage and incomprehension, he signals his irrational opposition to God's will, and hence his status as an earthly tyrant. Such scenes are important primarily for the delineation of dramatic character rather than the driving of plot. They tell us how to respond to figures and mark out their role in the wider story to follow (a feature that we will encounter again in Cleopatra's receipt of the Messenger in Shakespeare's Antony and Cleopatra).

When, in the Coventry Shearmen and Taylors' Play, the Angel Gabriel appears before the Virgin, she is "amacid" (49) and troubled in spirit. The messenger greets her with impeccable courtesy: a mark both of her status as the future Queen of Heaven and of his tact and discretion.

Dred the[e] nothyng, meydin, of this.

From heyvin abowe hyddur am I sent

Of ambassage from that kyng of blys

Unto the $[e]$, lade and virgin reverent $[\ldots](50-54)^{3}$

Mary's only possible failing is her temporary inability to understand how the news that Gabriel brings could apply to her, given her humble status and avowed virginity. Once he has assured her that it is God's intention that she should bear His Child, she readily agrees to perform her allotted role in salvific history. The York Gabriel, sent to reassure Joseph concerning his wife's pregnancy in Joseph's Troubles About Mary, performs a similar function. His tidings are not news to the audience, who already know that Mary is innocent of adultery, and they are not fundamentally surprising even to Joseph himself. He has already revealed an awareness of the prophecy of the virgin birth; it is, again, simply its applicability to him and his young bride that he cannot comprehend, creature of merely human rationality that he is:
But wele I wate [know] thurgh prophicie

A maiden clene suld bere a childe,

But it is nought sho [not her], sekirly,

Forthy I wate I am begiled. (61-64)

Again the crucial issue is not so much what the messenger says as how the recipient reacts to it, and Joseph, like his spouse, passes the test. Similarly the willingness to receive God's word of those other "natural men" the shepherds, visited on the night of the Nativity, symbolises the redeemable nature of humanity. It is revealing that the shepherds often do not even have to comprehend the content of the message the angel brings to be able to respond to it positively. In the Chester Shepherds' Play the Angel's song, "Gloria in excelsis deo, et in terra pax honinibus bonae voluntatis" ("Glory to God in the highest and on earth, peace, good will towards men", Luke 2:13-14), initially mystifies its hearers ("Hit was 'glorus glorus' with a 'glee'; / Hit was neyther more nor lasse", 383-84). But they are transformed by it nonetheless, intuitively deducing the meaning of the star through grace: "Now wend we forth to Bethlem, / [...] For to see the starre gleme, / The fryt alsoe of that mayden free" $\left.^{\prime \prime}(459 ; 461-62)\right)$.

Conversely it is the hallmark of the devils and demons, and the irredeemable human villains: Herod, Pilate, and Annas and Caiaphas that they respond to the Good News of the Incarnation with incomprehension, anger and denial. They, like the devils in the York Harrowing of Hell pageant, cling to the letter of their familiar OId Law(s) rather than embrace the mysteries of the New. Hence, even as Christ approaches to lead the souls of the virtuous from Limbo, Belsabub is certain that "Whils I am prince and principall / Schall pei never passe out of pis place" (York, Harrozving of Hell, 105-12). Similarly, when the Centurion who has witnessed the Crucifixion tells Pilate and the High Priests that he believes Christ was God's Son, they angrily reject his testimony, setting their worldly wisdom and will to evil against each piece of miraculous evidence that he cites. Consequently they enter into a conspiracy to conceal the news of Christ's divinity, suppressing word of the Resurrection itself in order to cling to power.

Pilatus. Thus shall pe soothe be bought and solde, And treasoune schall for trewthe be tolde.

$(450-51)$

The buying and selling of truth (a theme that, as we shall see, would greatly exercise Ben Jonson) and the setting up of treason in its stead by worldly powers are central motifs of the cycle plays. In the York pageants, a pure, divinely-inspired communication - the incorruptible, inmediate truth-telling of angels, prophets and witnesses to faith - is set against a fragmented, frustrating system of corrupt 
sublunary communication. The latter, a product of the uncertain, overlapping and anxiously competing jurisdictions of the Sanhedrin, Pilate's Imperial overlordship, and Herod's royal fief, reads the power structures described in the gospel accounts of the Passion and subsequent apocryphal and devotional texts through the particular social realities of late-medieval York..$^{5}$ Coming and going, entering and exiting in shuffling supplication between one authority and the next are, of course, emblematic of the lot of sinful, fallen humanity in the medieval Catholic worldview. As Chaucer has Egeus say in The Knight's Tale:

The world is but a thurghfare of wo,

And we been pilgrymes, passynge to and fro. I(A) (2847-48)

But in late-medieval York this constant perambulation must also have been a very immediate and obvious feature of everyday life. Within the bounds of the city a whole patchwork of interlocking jurisdictions competed for attention and privileges in the spheres of religious, economic and social life. ${ }^{6}$ In such a situation, no one body could speak unequivocally for the city, and authority was left fragmented, to be repeatedly tested and contested on a daily basis.

The elaborate machinery of announcement and revelation in the cycle plays is overtly a function of political activity. Each despatch of a messenger, nuncio or beadle stakes a particular claim to status and power within an unsettled political sphere. Most obviously these worldly messengers, heralds and military envoys are the servants of kings, and their function part of the cycles' delineation of true and false kingship. The spontaneous yet formally precise acts of reverence of the angels who sing praises to their God in the Creation pageants generate an endlessly circulating economy of "Good News" into which the virtuous characters are permitted a privileged insight at moments of revelation; while God the Father's use of angels and prophets to deliver promises and admonitions represents the correct use of the protocols of communication. Conversely, the blasphemous parodies of royal authority, courtly protocol and message-craft in the courts of the corrupt earthly monarchs, Pilate and Herod, represent its antithesis. Messengers are thus inextricably linked to the performance of royal authority in these plays. Herod is consistently the most blasphemous of the parodic kings, and his use of language and proclamation is appropriately bombastic. His claims to universal power are as vaunting as they are ridiculous. In the Coventry Shearman and Taylors' Play he claims for himself God's power over creation:

For I am evyn he that made bothe hevin and hell, And of my myghte powar holdith up pis world [rownd.
All the whole world from the north to pe sowthe, I ma them dystroie with won worde of my

$$
(448-49)
$$

[mowthe.

Such claims are manifestly absurd, since the audience has probably witnessed God's creation of heaven and earth $a b$ initio in the opening pageant - if the Coventry play follows the example of the other cycles. Yet, as the last line makes clear, Herod's claims to power are intimately bound up, not with demonstrable truths, but with claims to the command of language. Power on earth is more a matter of how one speaks than of what one says. Worldly authority can be fashioned from the command of discourse - or at least the kind of authority coveted by Herod can.

Herod's court is characterised in the York, Wakefield and Coventry plays by a bizarre macaronic discourse that conspicuously parodies the Latinate language of Heaven. In York Herod addresses Christ in a mixture of Latin and English that is clearly intended to echo God the Father's speech in the creation pageant.

Nowe sir, be perte $Y$ pe[e] pray,

For none of my gromes schall greve pe[e].

Si loqueris tibi laus,

Pariter quoque prospera dantur;

Si loqueris tibi fraus,

Fell fex et bella parantur. (260-63)

[If you speak well on your own behalf,

You will be well treated accordingly,

But if you speak badly on your own behalf,

Poison, filth and violence will follow. $]^{7}$

The use of Latin, the language of the church and the vulgate Bible was freighted with powerful associations of authority and doctrinal authenticity. It was, as Janette Dillon observes, "the fixed word out of time", as opposed to the compromised, unueliably temporal vernacular. ${ }^{8}$ Hence Latin is the language in which God begins the cycles in York, Chester and $\mathrm{N}$-Town, and is the tongue in which divinity, the prophets, patriarchs and saints express the highest mysteries they have to impart. So the transgression is all the more shocking on those few occasions, as in Satan's citation of Scripture or Herod's macaronic speeches, when Latin's sacral resonances emerge from the mouths of the enemies of God.

But the macaronic language of the Herodian court performed a political as well as a religious function, as is evident in its use of a burlesque version of French alongside the Latin and demotic English it employs. French, like Latin, was a language with distinct ideological baggage in the late-medieval period. The use of variations of Anglo-Noman in the law courts and an approximation of "standard" 
French among the aristocracy in previous centuries gave French a high social status and associated it with the ruling élite and the institutions of central govermment. Yet its association with the court also linked it to the conventional court vices of immorality, excess and affectation. It was thus more often to be encountered in vernacular English literature as the language of the poseur than the aristocrat. More significantly too, after the onset of the Hundred Years War, Frenchified manners also suggested potentially divided political loyalties. Hence the political edge to the scandal a century later, when Henry VIII's "Minions" were temporarily expelled from court for being "too French".9 As a consequence of such associations, the French language became a favourite marker of moral degeneracy in the literature and drama of the period. In the early sixteenth-century morality Hick Scomer, Free Will re-enters the place calling for room in a mixture of English and French that symbolises both his corruption and his newfound social pretensions:

Make you room for a gentleman, sirs, and peace!

Dieu garde, seigneurs, tout le presse! (646-47)

In the late fifteenth-century play Wisdom, the characters Mind, Will and Understanding signal their fall from grace by adopting vices that were the "gyse [fashion] of France" $(767) .{ }^{10}$

There is, then, a political agenda evident in the Herodian court's fascination with the French langutage. In the York pageant of Christ Before Herod, the latter's "Dukes", referred to by the king using the corrupted French word "bewschers" ("beau-sires"), address their sovereign in a curious, comic Franglais which they evidently consider the height of courtly decorum. Herod himself greets Christ in the same vein with only marginally more accomplished eloquence:

Saie, beene-venew in bone fay,

Ne plesew et parle remoy? (145-46)

[Welcome, in good faith,

Does it not please you to speak to me?]

In the Wakefield play of Herod the Great, Herod similarly lards his speeches with mangled French phrases, calling one of his soldiers "bewshere" (395), and attempting the phrase "dites sans doutance" - he manages "ditizance doutance" (247) - before conceding defeat with a final, "adew: to the devyll, / I can [know] no more Fraunch" (740-41). "11 Here language as means of communication comes into direct collision with language as a means of self-fashioning. In the Coventry pageant tyrannical bombast and Franglais are brought together in the opening speech of Herod's Nuncio, a messenger who addresses an audience of imaginary courtiers and real spectators in an extended, and to most of those present presumably incomprehensible, display of linguistic affectation.

Faytes pais, dnnys, barony, de grande reynowne, Payis, seneoris, schevaleris de noble posancë $[\ldots]$ $(421 \mathrm{ff})^{12}$

To this Herod responds with a macaronic boast drawn from the offertory verse, "Qui statis in Jude et Rex Iseraell / And the myghttyst conquerowre pat eyver walked in grownde" (436-37), before launching into the vaunting rant quoted above.

What was originally, perhaps, simply a reflection of social realities (the late-medieval English court did speak a variation of Anglo-Norman) became in the course of the following 150 years (as the play was reproduced, so far as one can tell, relatively unchanged) an increasingly remarkable aspect of Herod's presentation. As the use of French declined at court and in the central institutions of government, Herod's "Frenchness" would have become more obviously an affectation: a neat inversion of the new idea of "the King's English". ${ }^{13}$ So at precisely the time that the Crown was imposing itself more insistently on the provinces and advancing the national and the vernacular in culture, language, and religion against the "usurped" foreign jurisdictions of the Pope, the producers of the cycle plays were consciously representing their principal model of worldly kingship as an alien and contemptible figure: a tyrant whose behaviour was as laughably bizarre as it was brutal. Significantly, the Coventry texts were copied (and probably revised) in March 1534, at the very height of Henry VIII's assertion of the Royal Supremacy. The contradiction between the two claims for monarchy could not have gone unnoticed.

As the crown strove to reduce regional independence and particularism in the interests of a unified nation state, these cycles tacitly reasserted the distinctness of the regional cultures that produced them. ${ }^{14}$ They refracted the proclamations, communiqués, and envoys of central government through the comic glass of Herod's vaunting, self-defeating demands for order and obedience. By presenting the communicative infrastructure of the crown as an affected travesty of true communication in which treason was encoded as truth and both bought and sold, the plays, and the communities which produced, received and affirmed them told a very different story to the news disseminating from London.

"You have heard much": Ambiguity, Gossip and Messengers in Antony and Cleopatra ${ }^{15}$

Medieval drama's use of the messenger is thus only partially to do with the development of plot. The di- 
chotomy described between revelatory messages testifying to the miraculous probity of the Godhead on the one hand, and the clumsiness of the language of the tyrant on the other, conspicuously demonstrates the ethical distinction between heavenly perfection and earthly iniquity. Thus, while the messenger's role is to impart information, that information is always inflected by the place from whence it comes, be it celestial or terrestrial. Although the supernatural element becomes less overt as we move from the medieval to the early-modern stage (though unearthly envoys are by no means absent, as Mephistopheles in Doctor Faustus and the Witches in Macbeth testify), the origins of Shakespearean messengers are no less important. In Antony and Cleopatra, the news of Fulvia's death, for instance, permits the intrusion of sober Roman values into the decadent world of Egypt, while in Cymbeline, Caius Lucius' demands for tribute bring the crushing weight of Roman imperialism to defiant Britain. However, a messen-

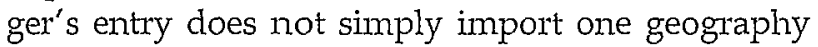
to another; the "foreignness" may also bring about a shift, often abrupt, in emotional tone. For instance, Mercade's news of the death of the princess's father turns Love's Labour's Lost from celebration to dark pessimism, while the anmouncement of the movement of Birnam Wood shatters the self-assurance of Macbeth, plunging him further into fearful anticipation. Hence the messenger, not only personifies an interface between two locations but frequently shifts the trajectory of the play.

It is widely acknowledged that Antony and Cleopatra is built upon the instability of truth. Although written thirty years ago, one of the most influential studies of the play is Janet Adelman's monograph, The Common Liar, whose very title is indicative of this relativity. ${ }^{16}$ Her opening chapter, subtitled symptomatically, "Uncertainty and Judgment in Antony and Cleopatra", describes how "both the presentation of character and the dramatic structure work to frustrate our reasonable desire for certainty ${ }^{\prime \prime}{ }^{17}$ This bewilderment occurs both diegetically and extradiegetically: difficulty of interpretation, unreliable evidence, wayward behaviour and imprecise detail serve to undermine the stability and substantiality of the characters, while an audience, confronted with what frequently turns out to be contradictory viewpoints, is often hard pressed to perceive adequately the order of things. ${ }^{18}$

It may be that post-modernity's insistence on the lack of coherence within a single character has proved so persuasive that such a postulate now appears little more than the outmoded bequest of Bradleian "character criticism". But the inconsistencies between story and performance which provide the source of much Shakespearean energy are, for the most part, easily explicable. For instance, in The Comedy of Errors we know there are two sets of identi- cal twins; in Tuelfth Night we know that Olivia's letter is not genuine and in Two Gentlemen of Verona, As You Like It, The Merchant of Venice and Cymbeline we know that the young boys are really women in disguise. But, as the titles cited imply, intrigue is usually a comic device; the audience, maintaining its position of superior knowledge over many of the figures on stage, is empowered by the latters' ignorance. That is why moments like the unmasking of the Abbess at the end of Errors or the statue of Hermione coming to life in The Winter's Tale are so alarming and indeed so rare. More usually the intrigues which animate comedy are, as it were, transparent.

In using this traditionally comic device in a play of such tragic weight as Antony and Cleopatra, Shakespeare is not merely confounding his characters but asking us to apply a trope taken from the comic arena to a very different genre. ${ }^{19}$ As such he is not merely writing about confusion but writing confusingly so that the substance of the play and the mode of its delivery (what we used to be able to call its "content" and "form") become synonymous. Antony and Cleopatra fragments into more separate units than any other play in the canon. As the action oscillates between Rome and Egypt, so its narrative line is continually broken and any aspiration to a unity of place, which might help an audience (especially in the non-illusionistic Globe theatre) grasp at least the location of the action is done away with. As Adelman puts it: "This frustration is not an end in itself: it forces us to participate in the experience of the play and ultimately to make the same leap of faith that the lovers make. In this sense, our uncertainty is an essential feature of the play." 20

Rumour, so dangerously personified at the opening of 2 Henry IV, reappears in Antony and Cleopatra to undermine political durability. Accounts of the Egyptian parties have scandalised the sober Romans, but Maecenas is incredulous: "Is this true?" (II.2.190) he demands of Enobarbus. As the astute Agrippa warns, justifying Antony's marriage to Octavia, "Truths would be tales, / Where now half-tales be truths" (141-42). But the real danger of gossip is that its source is always anonymous. Two unnamed soldiers discuss events immediately prior to the mysterious desertion of Antony by his guiding spirit, Hercules:

2 Soldier. Heard you of nothing strange about the [streets?

1 Soldier. Nothing. What news?

2 Soldier. Belike 'tis but a rumour. Good night to

(IV.3.3-5) [you.

The soldiers' anxious huddle is a perfect illustration of Antonio's maxim: "What great ones do the less will prattle of" (Twelfth Night, 1.1.29), but we never hear what this rumour might be because their talk 
is rapidly eclipsed by the sorcerous hautboys and the soldiers' monosyllabic, panicked exchanges, "Peace! [...] List, list! [...] Hark! [...] Peace, I say!" (13-20). It is as though the uncanny music of Hercules has silenced the men's quotidian demotic. But this is the only instance of transcendental censorship as the two voluble worlds, Rome and Egypt, exchange increasingly inaccurate representations of each other's inhabitants and events.

In the very first scene, the estimation of Antony is traduced by the "common liar" (1.1.61) in Rome, a fate which Cleopatra's reputation shares, as Antony well appreciates, subsequently ordering a messenger to "mince not the general tongue; / Name Cleopatra as she is called in Rome" (I.2.111-12). Later in his charm offensive against Octavia, Antony urges her to "Read not my blemishes in the world's report" (II.3.5) as though he realises the importance of a political identity untarnished by the rumours attaching to his luxuriant lifestyle in Alexandria. Significantly, the diversity of their political methods can be seen in the reactions of Cleopatra and Antony to gossip. The Queen of Egypt is unconcerned by the Latin chattering classes: "Sink Rome, and their tongues rot / That speak against us!" (III.7.15-16). Antony, weaned in the cautious Roman way, is more circumspect and laments the loss of social distinction: "I have offended reputation, / A most unnoble swerving" (III.11.4950). The vehicle by which these reputations are won and lost, disseminated and exchanged, is of course the play's plethora of messengers.

While the intrigue plot used in Antony and Cleopatra is, as we have seen, similar to that of the comedies, its fabrication derives from the circulation of news and gossip via a series of more or less reliable messengers. Shakespearean comedy, on the other hand, is largely devoid of messengers. There are none in The Taming of the Shrew, The Two Gentlemen of Verona, A Midsummer Night's Drean or The Merry Wives of Windsor while As You Like It, The Conedy of Errors and Love's Labour's Lost use only one apiece. Much Ado About Nothing and The Merchant of Venice have only two each. ${ }^{21}$ Thus we may conclude that despite the use of a kind of plotting which is more at home in a comedy, Antony and Cleopatra constructs its intrigue in a very different way.

In Antony and Cleopatra messengers are ubiquitous. They are at once the conduit for the flow of information between the two worlds of Egypt and Rome; the means by which Shakespeare offers his audience an interpretative life-line given the play's geographical and temporal mobility; the vehicle by which, as in the cycle plays, the character of the addressee is assessed by the audience. Yet this gauging of the addressee by their receipt of a message also occurs within the fiction of the play. Cleopatra sends Alexas to Antony to "See where he is, who's with him, what he does" (I.3.3). Yet the substance of Alexas's message must be formulated in direct opposition to the attitude of its recipient: "If you find him sad, / Say I am dancing; if in mirth, report / That I am sudden sick" (4-6). Critically, the delivery of the message must seem incidental: "I did not send you" (4). In these cases the function of the message has nothing to do with the reporting of fact, indeed, its substance is irrelevant since it is improvised according to thercondition of its addressee. Armed with such a strategy for assessing the commitment, as she thinks, of her lover; Cleopatra reuses the device, tragically overstepping the mark: "Mardian, go tell him I have slain myself [...] And bring me how he takes my death. To th' monument!" (IV.13.7-10). .The sole function of Cleopatra's fictional message is to determine "how he takes my death". This is phatic communication at its extreme, all substance gone.

The prominence of messengers is both a symptom and a cause of the ambiguity described above since it seems there are as many different versions of the "truth" as there are messengers to report it. At I.4.34, a messenger enters to notify Caesar of Pompey's superiority at sea. What is noteworthy about his report is not its substance, since that is something Caesar half expected - "I should have known no less" (40) - rather it is the messenger's assurance that Caesar. will be kept up to date with regular hourly bulletins: "Thy biddings have been done, and every hour, / Most noble Caesar, shalt thou have report / How 'tis abroad" (34-36). As if to illustrate the efficiency of this system, seven lines later another messenger enters: "Caesar, I bring thee word [...]" (48). The effect of these successive hurried entries is to suggest a rapidly changing situation and the kinds of political instability noted above. Messengers serve here not merely to disseminate certainty but to undermine it.

In their contrasting use of messengers the protagonists illustrate their own differing political priorities. Rome's messengers form an international circuit of vigilance which reports back to the centre. As M. M. Mahood writes, "While Antony has been ignoring messages from a world of affairs that for him has lost its reality, Octavius Caesar in Rome has remained as responsive as a spider at the centre of his network of intelligence". ${ }^{22}$ Caesar is incandescent at the reports he has received of Cleopatra's public coronation as Queen of Syria, Cyprus and Lydia (III.6.10). Enthroned in the market place by Antony, Cleopatra is a public monarch, combining the power of high politics with popular support - all this " $I$ ' th' common showplace" (12). Caesar has spies everywhere as he assures his sister in a remark which oddly describes his sinister surveillance in the most innocuous terms: "I have eyes upon him, / And his affairs come to me on the wind" (III.6.63-64).

Roman messengers are menacingly ommipresent. Within the first eighteen lines of the play, a messenger enters with "News, my good lord, from Rome" 
(I.1.18) and when Antony refuses to hear them, Cleopatra goads him, "Call in the messengers! [...] The messengers!" (30-33). Antony, desperate it seems to demonstrate his independence from Roman imperialism, refers himself to Cleopatra and silences the messenger, "No messenger but thine [...] Speak not to us" (1.1.53-56). Yet, in the very next scene, unobserved as he thinks by Cleopatra, Antony enters, ensconced with the messenger from whom he receives the account of Fulvia's rebellion (I.2.92f). The damage, however, has been done and Caesar hears of the disrespect with which his messengers are treated, "You / Did pocket up my letters, and with taunts, / Did gibe my missive out of audience" (II.2.77-79). Spurning the Emperor's messenger is treasonable, as Shakespeare elsewhere demonstrates. Coming across his emissary in the stocks, King Lear is outraged, "They durst not do't; / They could not, would not do't. 'Tis worse than murder" (King Lear, II.2.198-99). Even worse punishment than stocking, however, is visited on Caesar's messenger when Antony catches him kissing Cleopatra's hand. When Thidias, whipped, is sent back to Rome, Caesar is personally affronted: "He calls me boy, and chides as he had power / To beat me out of Egypt. My messenger / He has whipped with rods; dares me to personal combat, / Caesar to Antony" (IV.1.1-4). The whipping of Thidias is thus not merely an unfortunate transgression of courtly etiquette; it is a gesture of treasonable defiance.

Caesar's messengers take on a particular significance towards the end of the play. Despite the fact that he is close by (Decretas has just brought him Antony's bloody sword), Caesar communicates with Cleopatra via a series of messengers. Of these only one is apparently trustworthy, having been vouched for by Antony: "None about Caesar trust but Proculeius" (IV.15.51). For all Antony's advice, however, Cleopatra is reluctant to trust anybody, even Proculeius ("Antony / Did tell me of you, bade me trust you, but / I do not greatly care to be deceived / That have no use for trusting" (V.2.12-15)). And her reservations prove justified; as he exits assuring her of Caesar's best intentions, Proculeius remarks to the soldiers "You see how easily she may be surprised. / Guard her till Caesar come" (V.2.35-36). This betrayal marks not only Cleopatra's intuitive understanding of the cynicism of Roman politics but also illustrates Antony's hopelessly naive appreciation of the messenger's integrity. In urging her to trust Proculeius, Antony has unwittingly offered her up to the authority of Caesar. In fact it is Dolabella who, taking over charge of the captive queen from Proculeius (63-67), informs her of Caesar's plans (108; 199-201). However, this news merely confirms her own previous suspicions and she is left with little option but to frustrate Caesar's procession by taking her own life. A nameless Guardsman ushers in the fig-bearing
Clown, little suspecting that the basket also contains the means by which his Emperor will be frustrated of his political triumph (V.2.232; 240). As the Guard rushes into the chamber, Charmian is triumphant that the Roman system of communications has broken down just long enough to permit her mistress to escape:

Enter the Guard.

1 Guard. Where's the Queen?

Clarmian. Speak softly. Wake her not.

1 Guard. Caesar hath sent -

Chamian.

Too slow a messenger: (319-20)

Ray L. Heffner nicely captures the irony of this treatment of the last messenger: "To this great coda, Shakespeare could not resist adding a final ironic and triumphant reminiscence of all those sweating, scurrying messengers who have filled the stage, now all too slow to catch Cleopatra's soaring spirit" ${ }^{\prime 23}$ Cleopatra and her women have frustrated Caesar's communicative effectiveness.

Antony too frequently uses messengers. At one point we see him receiving three in quick succession. The first describes the rebellion of Fulvia. Immediately following his exit, another enters with the news of the arrival of a third (I.2.121). This last enters with a letter and the report of Fulvia's death (124). In less than ten lines three messengers have appeared and exited; clearly this is a government in crisis. As. Marion Perret writes, "The soldier turned strumpet's fool is recalled to duty by messages from beyond his realm of pleasure". ${ }^{24}$ But this recall falls on deaf ears and later in the play the situation has grown so bad that Antony is forced to rely on a schoolmaster to carry his messages. Plutarch explains: "And bicause they had no other men of estimacion about them, for some were fledde, and those that remained, they did not greatly trust them: they were inforced to sende Euphronius the schoolemaister of their children". ${ }^{25}$ Later, not even the schoolmaster remains to deliver Antony's reports and Antony has to take them in person: "Where yond pine does stand / I shall discover all. I'll bring thee word / Straight how 'tis like to go" (IV.12.1-3).

Not only is Antony's authority over messengers inferior to Caesar's, he finds himself humiliated by them. When he demands of the impertinent Thidias who he is, the messenger responds with "One that but performs / The bidding of the fullest man and worthiest / To have command obeyed" (III.13.91-93). "Authority melts from me" (95) laments Antony before defying the messenger (and so his master) with the petulant command to have him whipped. His very identity is under attack and his declamation: "I am Antony yet" (98) exposes this insecurity.

While Caesar shrewdly used messengers to gather intelligence, Cleopatra uses them as public gestures. 
We hear that she has despatched "twenty several messengers" (I.5.65) after Antony, and when challenged over this profligacy by Alexas, she declaims "Who's born that day / When I forget to send to Antony / Shall die a beggax" (66-68). With typically apocalyptic hyperbole she declares: "Get me ink and paper! / He shall have every day a several greeting / Or I'll unpeople Egypt!" (79-81). For Cleopatra, messengers are another mode of extravagant display, communication already has that phatic dimension that will ultimately prove tragic.

Perhaps the play's most extended and comic exploration of the role of the messenger occurs in Act II Scene 5 and Act III Scene 3. During these paired scenes, Cleopatra receives news of Antony's marriage to Octavia. While the gap between these scenes is occupied with the feast on Pompey's barge (II. 6 and II.7); the victory of Ventidius over Pacorus in Syria (III.1); and the banter of Agrippa and Enobarbus in which we hear of Lepidus' hang-over which implies that several hours, if not a whole night have passed (III.2.6), the link between Act II Scene 5 and Act III Scene 3 is apparently seamless. The First Folio insists on the continuity of the exchange with the SD, "Enter the Messenger as before". The implication seems to be that while the world of high politics has moved on, Cleopatra's obsession with Antony constrains the scope of her horizon. In this way then, Shakespeare uses messengers not merely to imply the immensity of the play's dramatic geography but to suggest a domestic and emotional claustrophobia.

In Antony and Cleopatra Shakespeare uses messengers in a variety of ways - their role may be narrative, symbolic or even bathetic. Their news may be directed at the addressee or may bring the audience up to speed with off-stage information. More usually, the impact on the recipient will be as consequential as the content of the message. But just as important, as we have seen, is the manner in which the apparently candid message is inflected by the circumstances of its delivery. Lloyd Davis has written of the ways in which the anonymity of telephone operators and internet service providers stage an intimacy between the communicants which protests the transparency of the medium through which such messages take place. But in Shakespearean drama, the medium is the messenger who serves both to consolidate and to challenge political and personal intercourse and so draws attention to the "discursive and mediated dimensions of [...] relationships and identities". ${ }^{26}$ The messenger serves to demonstrate the ways in which people are shaped by the politics of the space they inhabit, but also suggests the ways they may interrogate and redefine that space.

Betwreen the employment of the messenger in medieval drama and its use on the early-modern stage there is an increasing secularisation and a scepticism towards transcendental truth. We have moved from the divine veracity of the Annunciation, through the inept propagandising of Herod, to the downright manipulation of news and information represented both diagetically and extradiagetically in Antony and Cleopatra. But it is with Ben Jonson's The Staple of Newes that the challenge to the benefits of communication is most pronounced. Here thot only is the reliability of the message's content demonstrated to be unstable but the very mode of its composition and dissemination is shown to be subject to the distorting forces of a market economy. News is not only reported, it is manufactured and sold, becoming just another commodity in a world where fullness brims and overflows into superfluity.

Communication as Commodity: The Staple of News

The most striking aspect of Jonson's The Staple of Neros is the clarity with which communication is conceptualised as a commodity. The ritualistic and symbolic elements of exchanging information and greetings characteristic of medieval plays are diminished and replaced in The Staple by concerns over the costs of access: "A groatsworth of any news - I care not what", entreats a countrywoman in the Staple office (I.1.10-11). ${ }^{27}$ Jonson's extreme scepticism concerning this trend is reiterated throughout the play, especially in the critical observations of the prodigal son's disguised father, Pennyboy Canter. What most disturbs character and playwright is not simply the passing of traditional linguistic and social relations but their replacement by commercially driven practices. The news business will reconstitute interpersonal rituals of information exchange as transactions in which the participants are motivated by material rather than ethical profit. For Jonson, the temptation to profit increases the likelihood that communication will be open to manipulation and distortion.

Jonson's views on the importance of honest language and communication are affirmed throughout his work, in poems, plays, masques and treatises. His commonplace book, Timber: or Discoveries, contains many such pronouncements. Throughout, he describes the present state of discourse and letters as an "epidemical infection" (360), full of lying and slanders. He denounces the prevalence of "foolish and affected eloquence" (424) and the contemporary prejudice that "right and natural language seems to have least of the wit in $\mathrm{it}^{\prime \prime}$ (716). "[E]loquence", he contends, "grows backward" (1138); language is becoming corrupt along with manners and fashions and people have forgotten that "talking and eloquence are not the same: to speak, and to speak well are two things" (2310). A key reason for this decay is that men engaged in learning and letters "think no learning good, but what brings in gain"; and their own work is prompted by "profits and fees" (1269). 
Financial motives have overtaken literary and ethical ones: "how hath all true reputation fallen, since money began to have any!" (1794).

In spite of the decrease in the quality of contemporary language and communication, Jonson is adamant that the importance of speech has not declined. It is an index of character: "Language most shows a man: speak that I may see thee" (2515). It is best able to convey that "Truth [which] is man's proper good" (659), and no more so than when authentic poetic language or poesy is practised. Jonson reproduces the terms of Philip Sidney's Defence of Poesy, conceiving poetry as "a dulcet, and gentle philosophy, which leads on, and guides us by the hand to action" (2973). Yet the moral imperative to express truth is restrained by other sorts of public demands: "men may by no means write freely or speak truth, but when it offends not" (2867). Social and commercial pressures threaten free and true speech, which, while everybody's prerogative, is best practised by genuine poets and dramatists. In its mixed form, part-allegory and part-city comedy, The Staple of Newus combines traditional and contemporary dramatic modes to stage the rapidly changing conditions that appear to be endangering the cultural roles and values of communication.

Many of these issues are given a preliminary airing in the court masque, News from the New World Discovered in the Moon, which proved popular with king and court, being performed twice in quick succession, in January and February 1620. By this time, the masque's hybrid structure was well established and here it enabled Jonson to juxtapose idealized and disapproved modes of communication. In its compact form the masque thus anticipates the doubled generic structure of The Staple. The danger to communication embodied by the representatives of the printing and news trades is ultimately transcended by the glories of sovereignty, which are proclaimed by a perfect new race, arrived from the moon. They sing and dance gracefully before the king, led by Prince Charles. This kind of majestic celebration erases the discussion of "news" at the opening of the masque and replaces it with "Fame, that doth nourish the renown of kings, / And keeps that fair which envy would blot out" (352-53). ${ }^{28}$ The final revels do more than publish fame as an exemplary discourse; they are a testament to the court artist's pre-eminent role among authors - his style and subject matter provide the paramount model for others. Yet, before this exclusive royal discourse can be embraced, alternative media must be surveyed. Various kinds of news and their providers are discredited by the authority and prestige that invest regal renown and its chroniclers.

The masque opens suddenly with two Heralds trumpeting the arrival of "Bold and brave news!" (2). Their very presence calls up the time-honoured, aristocratic means of transmission that we have seen dramatized in earlier plays; the address to the masque's elite audience seems designed to endorse their privileged access and reception of information. But onstage, professionals, not courtly figures are there to hear the news. They immediately weigh up its material wrorth. "What's the price of 'em?" (8) asks the Printer, to the Heralds' scom. "What price but the price o' your ears. As if any man used to pay for anything here!... You should be some dull tradesman by your pigheaded sconce now, that think there's nothing good anywhere but what's to be sold" (913) is their anti-commercial response. The Printer's words have threatened to demystify the process of the Heralds' presentation, implying that all news, no matter how grandly delivered, has its price:

Indeed I am all for sale, gentlemen [...] I am a printer, and a printer of news, and I do hearken after 'em wherever they be, at any rates; I'll give anything for a good copy now, be't true or false, so't be news.

(14-17)

What constitutes "good copy" for the Printer is a story's material value. At one level, this is simply what it can be bought and sold for; at another, it entails the story's exchange value for both those who wish to distribute it and those who might be interested in reading or hearing it. The implication is that a wide group, rather than the author alone, is involved in establishing the appeal and worth of a text, and perhaps in effecting critical judgment of it too. The author and his select audience are no longer in an exclusive position of deciding what is "good" about the copy.

The Chronicler and Factor are likewise conscious of financial matters. They reveal that textual genres exist within an economy of production and reception that complicates Jonson's dearly held Horatian model of literary distinction: "the maker's double scope, / To profit and delight" (Staple, 1-2). Given their position within the publishing system - mediating between suppliers, distributors and readers - it might be expected that the Printer, Chronicler and Factor will "think no learning good, but what brings in gain" (Timber, 1268). The Chronicler, for instance, reports "matter of state" (19) and is contracted to a stationer to produce a manuscript of "three ream of paper at least" (21). He remains short of facts, hence his interest in what the Heralds have to say: they might be able to provide him with new material. Though he claims "to give light to posterity in the truth of things" (28), contractual requirements and the speed with which he can work are the Chronicler's primary concerns.

Rapid service is also an issue for the Factor, who distributes news to "all the shires of England" (31-2). Having to write as many as twelve hundred newslet- 
ters a week, he is compelled to "maintain the business at some charge, both to hold up my reputation with mine own ministers in town and my friends of correspondence in the country" (33-36). The Factor has rationalised the process to provide varied kinds of news to different groups of readers, "an answering catalogue of dispatch wherein I have my Puritan news, my Protestant news and my Pontifical news" (37-39). Nevertheless, he too depends heavily on others - delivery networks, news providers in the city, and clients in the country. For this reason, he envisages moving the service onto a more solid business base: "I have hope to erect a staple for news ere long, whither all shall be brought and thence again vented under the name of staple-news" (41-42). He is aware of the importance of certification of news, even if it is no more than a branding or merchandising exercise. Similarly, in Jonson's play, the news is to be authorized and stamped "With the Office seal: Staple Commodity" (Staple, I.5.63). The Factor's viewpoint suggests that textual value might not solely be an intrinsic effect of style, meaning and the discernment of author and reader.

These business plans lead to a brief but revealing dispute between the Factor and the Printer over how news is best defined. Each delivers specious, self-serving explanations, but both suggest that the forms of presentation and production are as crucial to generic categories and readers' responses as are textual features of style and content. Since the Factor uses handwriting, he claims, "it is the printing I am offended at" for demeaning the quality of news (53). In fact, he would forbid it, "for when they are printed they leave to be news. While they are written, though they be false, they remain news still" (54-55). We can imagine the masque audience, most of them faithfully subscribing to Jacobean political imagery, laughing heartily at the glib dismissal of a link between news and truth. However, the Factor's words emphasize the roles of presentation and technology in creating meaning for readers. The older skill of handwriting carries, so he suggests, an authenticity which printing lacks. Ironically, the critical gist of his claims can be extended to the elaborate and expensive workings of the court masque itself, that "illusion of power" whose effects are based on new theatrical modes and stage machinery. ${ }^{29}$

The Printer disagrees with the Factor's preferred mode but actually confirms his assumption that the meaning of the message resides in its medium: "It is the printing of 'em makes 'em news to a great many, who will indeed believe nothing but what's in print" (57-59). In this view, in the 144 years since Caxton set up his press in Westminster, print has attained the aura of true discourse, regardless of what it presents. For the purposes of Jonson's satire, the Printer exaggerates; he does so in character too, partly to enlarge his own importance. Yet his words do suggest the way that, to a significant extent, determinants of meaning and response are materially grounded. Textual presentation and accessibility are crucial. Having carefully seen his elaborate Folio of Works through the press in 1616, it is a point of which Jonson was no doubt well aware. The Printer takes it to a commercial extreme. For him, the use-value of news not its truth-value is what finally counts:

$$
\therefore \text {. }
$$

I do keep my presses and so many pens going to bring forth wholesome relations, which once in half a score years (as the age grows forgetful) I print over again with a new date, and they are of excellent use. (59-62)

Repetition, reproduction, generic formulae - these are all staples of popular media, and, paradoxically, of courtly discourses too. The Printer intimates the scale of labour and material needed to stimulate shape and supply the public's appetite for news - satisfaction rather than edification is crucial.

It is tempting, again, to compare these requirements to the capital involved in staging a court masque and the way Inigo Jones and Jonson had to educate their audiences to follow its innovative visual and verbal codes. However, Jonson challenges any such analogy at the pivotal moment of the masque, following the antimasque dance by the aberrant epicoene figures, the "Volatees" (269), who seem to embody all the excesses of the bizarre characters reported in Jacobean tabloid-style news-sheets. After their discordant dancing, the Second Herald concedes to the audience, and specifically the king, that thus far "we have moved rather to your delight than your belief. But now be pleased to expect a more noble discovery worthy of your ear [...] led by that excellent likeness of yourself, the Truth" (271-83). Viewers are invited to follow the shift in tone and move to a higher plane of meaning; we transcend the apocrypha of news and "Read" instead "the book / Of all perfection" (310-11). The masque's stage magic of verse, dance, costume and lighting helps Jonson to resolve the challenge posed by news to the discursive status quo and to cement the superiority of the court artist and playwright in imparting true knowledge to readers and viewers. The question remains, however: is this the information they want?

Like News from the New World, The Staple of News contains a pivotal transition, between Acts II and III, from the miserly Pennyboy Senior's house into the office of the Staple itself. The allure of the Staple is borne out first by the gossip Expectation's eagerness to see it in the second Intermean, "I expect their Office, their great Office, the Staple, what it will be!" (2.Int.48-49), and then by Pennyboy Junior's greedy curiosity about incoming stories - he ends up buying them all; "Let me have all this news made up and sealed" (III.2.110) - and the swell of customers, whose clamour for news rises to a crescendo: "I'll 
ha' that news. / And I. / And I. / And I. / And I. / And I" (III.3.312-13). The unreality of the Staple and the world it represents appears to be proven by the office's chimerical disintegration, "Shivered, as in an earthquake" at the beginuing of the play's fifth act (V.1.40). It seems to have been no more than an alchemist's still. ${ }^{30}$

Though the onstage action leads unequivocally to this conclusion, the author of the play feels compelled to add a note, "To the Readers", in the published version, which clarifies the implications for interpreting the news presented by the Staple. There was a delay of at least five years between the play being written and produced in 1626 and a folio printing of The Staple, along with The Devil is an Ass and Bartholonew Fair, in 1631, which was circulated among patrons and friends. ${ }^{31}$ Jonson had time to gauge audience reactions, about which he was usually vitriolic, and sought to guide the responses of a selected readership. He dismisses the ways in which "the allegory and purpose of the author hath hitherto been wholly mistaken" and beseeches his readers "thus to mend it":

To consider the news here vented to be none of his news, or any reasonable man's, but news made like the time's news (a weekly cheat to draw money) and could not be fitter reprehended than in raising this ridiculous Office of the Staple, wherein the age may see her own folly, or hunger and thirst after published pamphlets of news, set out every Saturday but made all at home, and no syllable of truth in them; than which there cannot be a greater disease in nature, or a fouler scorn put upon the times. And so apprehending it, you shall do the author and your own judgement a coutrtesy, and perceive the trick of alluring money to the Office and there cozening the people.

("To the Readers", 7-18)

In one sense, Jonson's defensiveness is not new - he had always been concerned about the way his work might be criticized and misread, as the contract defining the audience's responses in the prologue to Bartholomew Fair humorously shows. Yet there is a difference here. Jonson finds that despite its critical point of view, his play has been subject to the influence of media discourse and the types of response that it promotes. Far from reflecting and evaluating the genre, The Staple is reproduced by it. And though it seeks to pre-empt heterogeneous responses by lampooning the reactions of the four gossips Mirth, Tattle, Expectation and Censure between each act, the play is caught in the free-for-all of public opinion, which was being augmented by the news's widespread circulation from the 1620s. The Staple is equated with what it would critique, a fate that suggests the public strength of media discourse, whose impact outstrips the judgement, no matter how "courteous", of any narrowcast audience.
In the middle scene of the play (III.2), the outpouring of news threatens to swamp the "reasonable man". It seems to carry a decadent, sensuous charge. Here fame is not an ideal sovereign discourse, as at the end of Jonson's masque. Instead it is an additional form of gossip, jeering and canting, the three other corrupt modes of contemporary verbal exchange that Jonson critiques in the play. The Register of the Staple offers Pennyboy Junior a striking description of how the office works, part-explanation, part-sales pitch:

'Tis the house of fame, sir:

Where both the curious and the negligent,

The scrupulous and careless, wild and staid,

The idle and laborious: all do meet

To taste the cornucopiae of her rumours,

Which she, the mother of sport, pleaseth to scatter

Among the vulgar. Baits, sir, for the people!

And they will bite like fishes.

(III.2.115-22)

Such cynical self-promotion may make him sound like an archetypal media mogul, but Register's claim that everybody comes to the Staple is notable: no one now remains unaffected by the news. With the play's performance at Blackfriars and at court in early 1626, spanning public and court audiences, there is a certain truth to his words. Even as it laments the rise of news media and commodity culture, and nostalgically envisages reconciliation between past and present that will "teach them all / The golden mean" (V.6.634), as D. F. McKenzie observes, The Staple "marks the end of theatre as the only secular mass medium, the end of the playhouse as the principal forum of public debate" ${ }^{32}$ It stages the opening of English society to changing forms and practices of communication whose effects are not fully understood or controlled by their providers, let alone their users.

Jonson offers no alternative to opposing these changes. He is concerned that the proliferation of news and communication is being engineered by interest groups for their own benefit and will lead to social fragmentation. He considers that news in particular constructs popular ignorance, and he rejects any possibility that the supply of and demand for news could affect social exchange and relations constructively. Nor does Jonson concede in The Staple or News from Nowhere that traditional genres, exemplified by the court masque, can also suppress and manipulate public knowledge. Rather he isolates these widespread discursive effects in news alone and exempts approved and traditional styles of texts from critical scrutiny. Hence the resolution of the prodigal son narrative in The Staple, with father and son reconciled and Pecunia granted to the erstwhile spendthrift, seems to reintroduce stability; the acceptance of time-honoured moral judgment assures personal and social futures. 
Though it is unable to imagine ways in which news systems will develop new kinds of social and cultural relationships, The Staple takes our analysis of communication practices in medieval and Renaissance drama to the threshold of the modem era. Like the cycle plays and Antony and Cleopatra it displays a subtle awareness of the manifold performative possibilities in the despatch and receipt of messengers and messages, but it also reveals a sharp awareness of the ways in which technological and institutional changes in communication affect both the public dissemination of information and the tenor and rhythms of everyday life, reflecting new fears about the commercial and technological aspects of information exchange of which earlier authors were largely free. Where the cycle plays betrayed an intense fear that news and information were being bought and sold as part of a diabolic plan to subvert redemptive history, The Staple fears the commercialisation of news for more pragmatic reasons. Taken together, however, these plays reveal that political manipulation of news and information, control of the media, changes in communications technology, the commodification of information or the reification of personal relations are not only modern concerns but were of great interest to medieval and early modern playwrights and audiences. Indeed, partnership in a very specific kind of exchange seems to have encouraged them frequently to stage and observe the benefits and pitfalls of communication.

Lloyd Davis, Peter J. SMITH and Greg WALKER

*The authors are very grateful to the British Academy and the Association of Commonwealth Universities for an International Joint Activities Award that funded the research on which this essay is based. Peter J. Smith and Greg Walker would like to dedicate the completed essay to the memory of Lloyd Davis; exemplary colleague, academic enthusiast, and friend.

\section{NOTES}

1. Timber: or Discoveries, in Ben Jonson: The Conplete Poems, ed. George Parfitt (Harmondsworth: Penguin, 1975), 373458. Line 2330 (references in the text are to line numbers).

2. James L. Kugel, ed., Poetry and Prophecy: The Beginnings of a Literary Tradition (Ithaca, New York: Cornell University Press, 1990), 1-25.

3. All quotations from the Coventry pageants are from Pamela M. King and Clifford Davidson, eds, The Coventry Corpus Christi Plays (Western Michigan: Medieval Institute Publications, 2000).

4. Rosemary Woolf, The English Mystery Plays (Berkeley: University of California Press, 1972), 122-23.

5. Woolf, English Mystery Plays, 238.

6. Greg Walker, ed., Medieval Drama: An Anthology
(Oxford: Blackwell, 2000), 80.

7. Quotations from the York pageants are from Walker, ed., Mediezal Drama and Richard Beadle and Pamela M. King, eds, York Mystery Plays: A Selection in Modern Spelling (Oxford: Clarendon Press, 1984).

8. Janette Dillon, Language and Stage in Medieval and Renaissance England (Cambridge: Cambridge ,University Press, 1998), 25 and 40.

9. For this incident, see Greg Walker, ed., Persuasive Fictions: Faction, Faith, and Political Culture in the Reign of Henry VIII (Aldershot: Ashgate, 1996), 35-53.

10. Walker, ed., Medieval Drama, 250.

11. Martin Stevens and A.C. Cawley, eds, The Towneley Plays, Early English Text Society SS 13 and 14 (Oxford: Oxford University Press, 1994), two vols.

12. King and Davidson, eds, Coventry Corpus Christi Plays, 234.

13. See Dillon, Language and Stage, 8.

14. For similar processes in Chester, see Tim Thornton, Cheshive and the Tudor State, 1480-1560 (Woodbridge: Boydell Press for the Royal Historical Society, 2000).

15. Antony and Cleopatra, II.vi.65. All references are from Arden III, ed. John Wilders (London: Routledge, 1995). References to the other works of Shakespeare are to the Compact Oxford Edition, eds Stanley Wells and Gary Taylor (Oxford: Clarendon Press, 1988).

16. Janet Adelman, The Common Liar: An Essay on Antony and Cleopatra (New Haven: Yale University Press, 1973).

17. Adelman, The Common Liar, 15.

18. Russell West, Spatial Representations and the Jacobean Stage: From Shakespeare to Webster (Basingstoke: Palgrave, 2002), 210

19. Michael Dobson and Stanley Wells, eds, The Oxford Companion to Shakespeare, (Oxford: Oxford University Press, 2001), 17.

20. Adelman, The Common Liar, 14.

21. Gary J. Scrimgeour, "The Messenger as a Dramatic Device in Shakespeare", Shakespeare Quarterly, 19 (1990), $41-54,42$.

22. M. M. Mahood, Playing Bit Parts in Shakespenre (London: Routledge, 1998), 183.

23. Ray L. Heffner Jr, "The Messengers in Shakespeare's Antony and Cleopatra", English Literary History, 43 (1976), $154-62,160$

24. Marion Perret, "Shakespeare's Use of Messengers in Antony and Cleopatra", Drama Survey, 5 (1966), 67-72, 68.

25. Geoffrey Bullough, ed., Narrative and Dramatic Sources of Shakespeare, (London: Routledge, 1964), eight vols, vol. 5, 305-06. 
26. Lloyd Davis, "'Living in the World': Communication and Culture in Early Modern England" currently unpublished, 7 and 13 .

27. The Staple of News, ed. Anthony Parr, Revels Plays (Manchester: Manchester University Press, 1988).

28. News from the New World Discovered in the Moon, in Ben Jonson: The Complete Masques, ed. Stephen Orgel (New Haven: Yale University Press, 1969), 292-305. Parenthetic references are to line numbers.

29. Stephen Orgel, The Illusion of Power: Political Theater in the English Renaissance (Berkeley: University of California
Press, 1975).

30. In The Alchemist, the still similarly explodes offstage (IV.5.78).

31. The play was not published until 1640: Parr, "Introduction", The Staple, 1-3. The narrow, personalized distribution of the 1631 folio is the antithesis of broadcast circulation crucial to the news services.

32. D. F. McKenzie, "The Staple of News and the Late Plays", in A Celebration of Ben Jonson, eds William Blissett, Julian Patrick and R. W. Van Fossen (Toronto: University of Toronto Press, 1974), 83-128, 126. 